\title{
COMPARATIVE ANALYSIS OF MEDICATION ASSORTMENT FOR CHRONIC OBSTRUCTIVE PULMONARY DISEASE TREATMENT PRESENTED AT UKRAINIAN AND POLISH PHARMACEUTICAL MARKETS
}

\author{
(C) O. I. Onyshkiv, T. A. Hroshovyi, I. P. Lech \\ Ternopil State Medical University by I. Ya. Horbachevsky
}

\begin{abstract}
Summary: it was made a comparative study of Ukrainian and Polish pharmaceutical markets of medications used for treatment of chronic obstructive pulmonary disease. Also it was analyzed the structure of the assortment of the researched group due to the manufacturing countries, dosage forms and composition of active pharmaceutical ingredients and their origin. The results of market research can determine the main ways of domestic assortment improvement of medications studied at the pharmaceutical and therapeutic group.
\end{abstract}

Key words: medications for treatment of chronic obstructive pulmonary disease, the pharmaceutical market of Ukraine and Poland.

Introduction. Nowadays, chronic obstructive pulmonary disease (COPD) is one of the biggest health problem. It is a major cause of morbidity and mortality in the world due to the medical, social and economic terms. Thus, according to the latest data of the World Health Organization, currently about 210 million people are suffering from COPD and more than 2.75 million people die of COPD each year [1]. Late diagnosis and inappropriate treatment lead to incapacitation and early disability. After 10 years, every fourth ill patient with COPD becomes disabled [2].

In accordance with the mentioned above information, comparative marketing analysis of medication assortment for the treatment of COPD are currently important at the domestic pharmaceutical market and at the market of Poland as one of the most developed markets of the European Union to determine the feasibility of developing new medications and the possibility to take the particular market field.

\section{Research methods.}

During the study it was used general rules for secondary collecting market information, methods of mathematical statistics. The information technologies are used for processing the results of the research. The analysis of the range of medication was done according to the classification of Anatomical Therapeutic Chemical (ATC) system using secondary information of electronic database of the State Registry of Medicines, Compendium, Pharmindex and data of information and analytical system «Baza leków DrWidget» [3-6].

Results and discussion. The objects of the study were medications of R03 group «Medications used for the obstructive respiratory diseases» (according to the ATC classification): adrenergic medications for inhala- tion use (group R03A), inhaled asthma agents (group R03B), adrenergic medications for regular use (group $\mathrm{R} 03 \mathrm{C}$ ), other medications for regular use of the obstructive respiratory diseases (group R03D) [6]. Market research of medications for the treatment of COPD was performed on various parameters, including the manufacturing countries, dosage form and content of active pharmaceutical ingredients and their origin.

Studying the medication assortment and patterns of R03 «Medications used for the obstructive respiratory diseases» at Ukrainian market showed that for the date of May 2015 the State Registry of Medicines included 18 trade names $(21.43 \%)$ of domestic production and 66 names $(78.57 \%)$ of foreign production, indicating a significant dominance of import at the research field of the domestic market.

These market analyses show that among foreign manufacturers of medication for COPD treatment at Ukrainian pharmaceutical market, 4 countries take the leading position: the Great Britain, Spain, Poland and India, the share of each country is $12.12 \%$ (8 medications) of researched assortment, Ireland and Sweden - $9.1 \%$ (6 medications) and $7.56 \%$ (5 medications) respectively. Overall offers come from pharmaceutical companies of 17 different countries to Ukrainian pharmaceutical market.

The domestic part of studied assortment of pharmacotherapeutic group at the pharmaceutical market in Ukraine is provided by 7 Ukrainian industrial enterprises, especially: Yuriya Farm, LLC; Mikrofarm, LLC; FF Darnitsa, CJSC; Borshchahivskyy CPP, PJSC; Niko, LLC; FF Health, LLC; Interhim, LLC.

As a result of market research in Poland, we found that the product assortment of R03 «Medications used

ISSN 2312-0967. Фармацевтичний часопис. 2015. № 4 
for the obstructive diseases of respiratory diseases" is mostly formed by foreign manufacturers. In particular, the number of foreign medications, of studied pharmacotherapeutic group, is generally higher in 4 times than the number of domestic medication production, indicating a significant dominance of import (80\%) at the studied field.

Based on the analysis of medications registered in Poland for COPD treatment due to the manufacturing countries, it was found that $21.74 \%$ (40 names) - medications produced in the Great Britain (leading manufacturers are GlaxoSmithKline, AstraZeneca), $18.47 \%$ (34 medications) - Germany (Boehringer Ingelheim, Sandoz), $11.96 \%$ (22 medications) - Switzerland (Novartis), and $7.07 \%$ (13 medications) of investigated assortment are produced in Israel (Teva Pharmaceutical Industries). Generally, the results of the research on importing countries for COPD treatment show that the delivery of these medications to the pharmaceutical market in Poland are performed by 18 countries of the world but their share of each totally is not higher than $5 \%$ of general assortment.

The domestic pharmaceutical company Orion Pharma ( 9 names) is a leader by the number of assortment items produced for Polish market, the second place has company Polpharma (7 names), the third place gets the company Polfarmex SA, which produces 6 medications for COPD treatment.

For more detailed study of investigation market fields, we have analyzed medications due to the form of release. In particular, analysis of the medication assortment for COPD treatment registered in Ukraine, due to the dosage forms has showed that the main share $(23.81 \%)$ is presented as aerosols, $19.05 \%$ of medications are powders for inhalation, $18.34 \%$ of researched group are coated tablets (Fig. 1)

Other medications, such as prolonged and chewing tablets, suspensions and solutions for inhalation, oral drops, syrups, solutions and powder injection, capsules, enteric and inhalation under pressure amount together approximately $48.80 \%$ of the assortment in this group at the market Ukraine.

The comparison of suggested assortment of R03 group, represented at the pharmaceutical market in Poland (Fig. 2) on medication forms, indicates that the largest share in this aspect are chewing tablets $-29.57 \%$ (68 medications), powders for inhalation - 22.60 \% (52 medications), coated tablets $-16.96 \%$ (39 medications) and aerosols $-13,04 \%$ (30 medications).

It should be mentioned that at the market of Ukraine in the assortment of the researched group there are no such dosage forms as modified capsules (Euphyllin Long, Takeda Pharma, Denmark), granules for oral solution preparation (Montelukast-1A Pharma, 1A Pharma, Germany) solution infusion (Theophyllinum, Baxter, USA) and rectal suppositories (Theovent 350, GlaxoSmithKline, UK).

The next phase of the study involved the research of proportion of medications for COPD treatment due to the origin of active pharmaceutical ingredients. The researched assortment of medications at Ukrainian market is represented only by synthetic medications. Medications based on montelukast (12 medications), the second place - theophylline (9 medications) and third

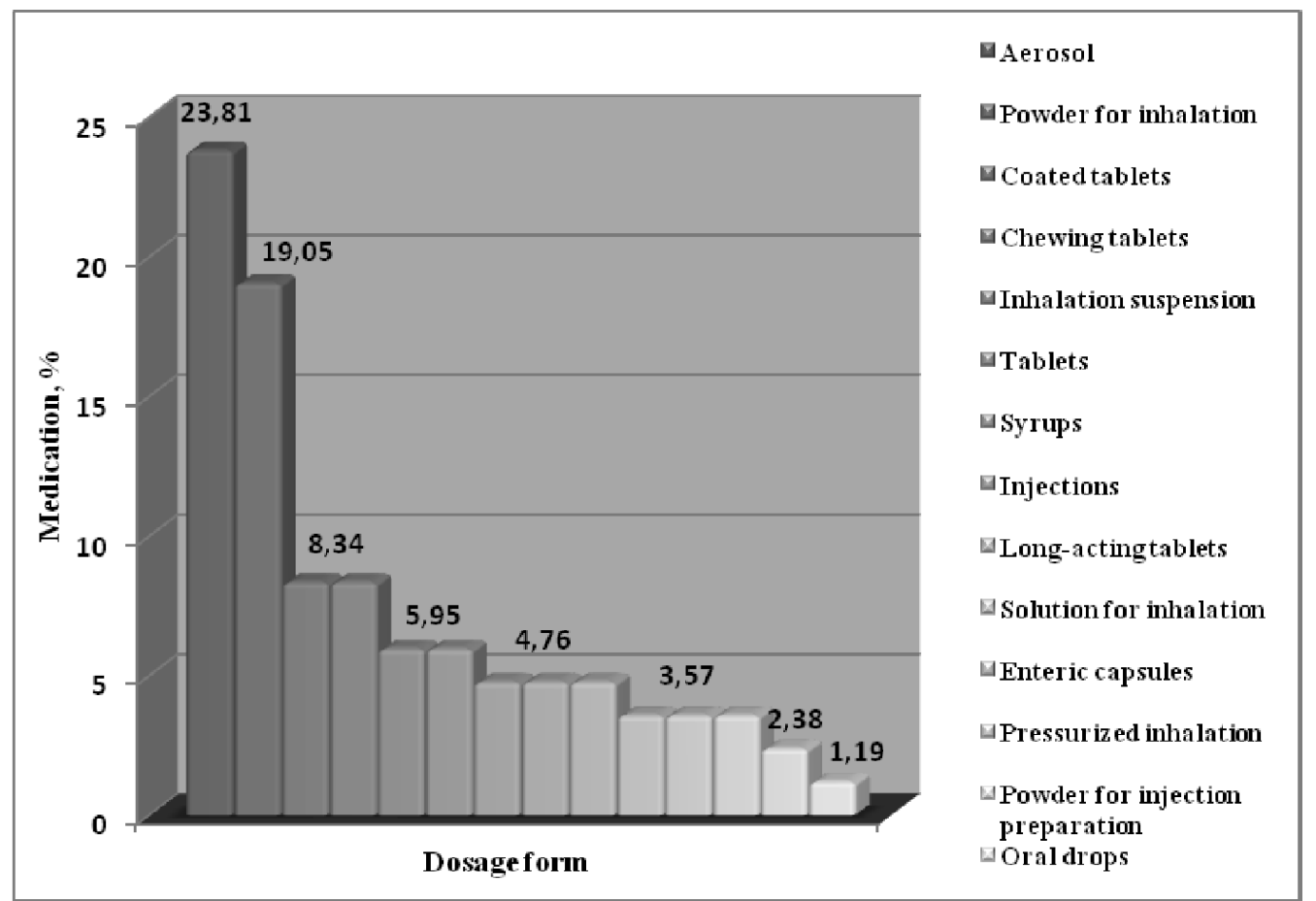

Fig. 1. Assortment distribution of medication for COPD treatment due to the dosage form at the market of Ukraine

ISSN 2312-0967. Pharmaceutical review. 2015. № 4 


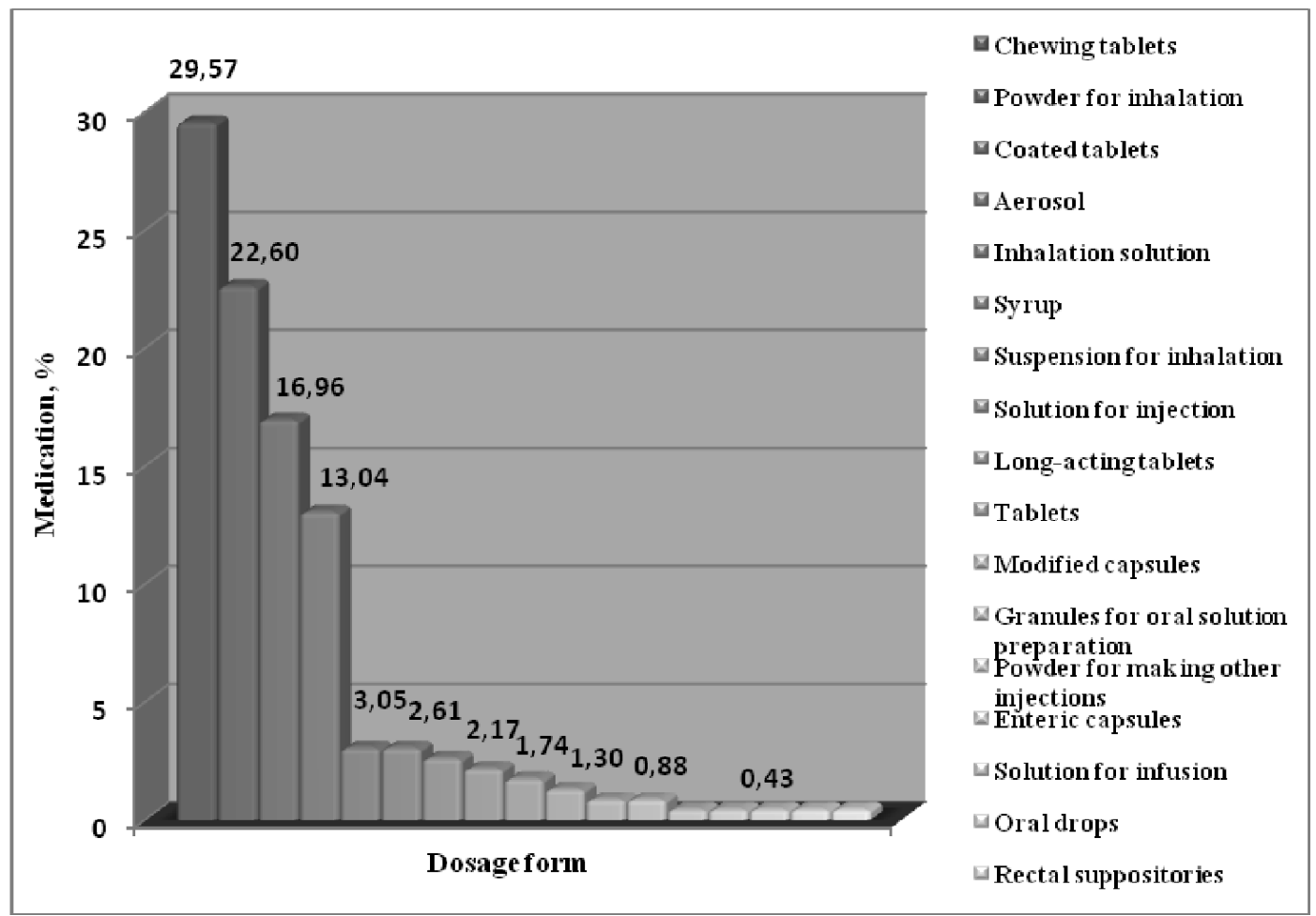

Fig. 2. Assortment distribution of medication for COPD treatment due to the dosage form at the market of Poland

- budesonide and fluticasone (8 medications) are the leaders of the researched group. It should be mentioned that monocomponent medications dominate among the studied medications. The share of combination medications is small $(17.85 \%)$.

The medication assortment for COPD treatment at Polish market is represented similarly as in Ukraine, only synthetic medications, while the main group of medications is based on montelukast (114 medications), the second place and the third place - salbutamol (17 medications) and budesonide (13 medications), respectively. The analysis of studied medications shows that amount of monocomponent medications (88.26\%) is bigger.

Comparative studies have shown the absence at the market of Ukraine the following active pharmaceutical ingredients and their combinations: combination - vilanterol and ipratropium bromide (trade name Anoro, Laventair, GlaxoSmithKline, UK); combination - indakaterol of glycopyrronium bromide (trade name Ultibro Breezhaler, Xoterna Breezhaler, Novartis, Switzerland); glycopyrronium bromide (trade name Enurev Breezhaler, Seebri Breezhaler, Tovanor Breezhaler Novartis, Switzerland); umeclidinium bromide (trade name Incruse, GlaxoSmithKline, UK); zafirlukast (brand name Accolate, AstraZeneca, UK).

A comparative studies of medication assortment for COPD treatment at the markets of Ukraine and Poland can determine the main ways for improvement of do- mestic assortment of medications at researched pharmacotherapeutic group.

\section{Conclusions:}

1. It was studied the medication assortment for COPD treatment listed on the pharmaceutical markets in Ukraine and Poland. As a result of studies, it was found that the products in both countries are generally represented by foreign manufacturers, particularly in Ukraine, their market share is $78.57 \%$, while in Poland $-80 \%$

2. The market analysis data indicates that among foreign manufacturers of medication for COPD treatment at Ukrainian pharmaceutical market leading positions are occupied by 4 countries: the Great Britain, Spain, Poland and India; at the Polish market, the following countries are the leaders of medication delivery: the Great Britain, Germany, Switzerland and Israel.

3. The comparison of assortment represented at the pharmaceutical market of Ukraine and Poland on the dosage form indicates that the largest share has aerosols $(23.81 \%)$ at Ukrainian market and chewable tablets (29.57\%) at Polish.

4. The medication assortment for COPD treatment is represented only with synthetic drugs at both pharmaceutical markets, while the main group in Ukraine is a group of medications based on montelukast, theophylline, budesonide, fluticasone and in Poland - montelukast, salbutamol, budesonide.

ISSN 2312-0967. Фармацевтичний часопис. 2015. № 4 
Фармацевтичний менеджмент, маркетинг та логістика Pharmaceutical management, marketing and logistics

\section{References}

1. Feshchenko Yu.I., Yashyna L.O., Potoczniak O.V. Chronic obstructive pulmonary disease and concomitant depression - an important medical and social problem // Ukrainian pulmonological journal. - 2013. - No.3. - P.56 - 58. - Access mode: http://www.ifp.kiev.ua/doc/journals/ upj/13_dop/56.pdf

2. Tytova O.N. Clinical and pharmacoeconomic approaches for effective medical rehabilitation of patients disabled by chronic obstructive pulmonary disease: abstract of the thesis of the Candidate of
Medical Sciences / O.N. Tytova - St. Pitersberg, 2008. $-25 p$.

3. State Registry of Medicines of Ukraine. - [electronic version].- Access mode: http://www.drlz.kiev.ua/

4. Pharmindex [ electronic version]. - Access mode: http:// pharmindex.pl

5. Baza leków DrWidget [electronic version]. - Access mode: http://drwidget.pl/

6. Compendium. - [electronic version].- Access mode: http://compendium.com.ua/

\title{
ПОРІВНЯЛЬНИЙ АНАЛІЗ АСОРТИМЕНТУ ЛІКАРСЬКИХ ЗАСОБІВ ДЛЯ ЛІКУВАННЯ ХРОНІЧНОГО ОБСТРУКТИВНОГО ЗАХВОРЮВАННЯ ЛЕГЕНЬ, ПРЕДСТАВЛЕНИХ НА УКРАЇНСЬКОМУ ТА ПОЛЬСЬКОМУ ФАРМАЦЕВТИЧНИХ РИНКАХ
}

\author{
О. І. Онишків, Т. А. Грошовий, І. П. Лех \\ Тернопільський державний медичний університет імені І. Я. Горбачевського
}

Резюме: проведено порівняльне дослідження українського та польського фрармацевтичних ринків лікарських засобів, які застосовують для лікування хронічного обструктивного захворювання легень. Проаналізовано структуру асортименту досліджуваної групи за країнами-виробниками, лікарською фрормою, а також вмістом активних фрармацевтичних інгредієнтів та їх походженням. Результати проведених маркетингових досліджень дозволяють визначити основні напрямки удосконалення вітчизняного асортименту препаратів досліджуваної фрармакотерапевтичної групи.

Ключові слова: лікарські засоби для лікування хронічного обструктивного захворювання легень, фрармацевтичний ринок України та Польщі.

\section{СРАВНИТЕЛЬНЫЙ АНАЛИЗ АССОРТИМЕНТА ЛЕКАРСТВЕННЫХ СРЕДСТВ ДЛЯ ЛЕЧЕНИЯ ХРОНИЧЕСКОГО ОБСТРУКТИВНОГО ЗАБОЛЕВАНИЯ ЛЕГКИХ, ПРЕДСТАВЛЕННЫХ НА УКРАИНСКОМ И ПОЛЬСКОМ ФАРМАЦЕВТИЧЕСКИХ РЫНКАХ}

\section{О. И. Онышкив, Т. А. Грошовый, И. П. Лех}

Тернопольский государственный медицинский университет имени И. Я. Горбачевского

Резюме: проведено сравнительное исследование украинского и польского фрармацевтических рынков препаратов, применяемых для лечения хронического обструктивного заболевания легких. Проанализирована структура ассортимента исследуемой группы по странам-производителям, лекарственной форме, а также содержанием активных фрармацевтических ингредиентов и их происхождению. Результаты проведенных маркетинговых исследований позволяют определить основные направления совершенствования отечественного ассортимента препаратов исследуемой фармако-терапевтической группы.

Ключевые слова: лекарственные средства для лечения хронического обструктивного заболевания легких, фармацевтический рынок Украины и Польши. 